The Crisis in Ukraine and the Split of Identity in the

Russian-Speaking World

\title{
The Crisis in Ukraine and the Split of Identity in the Russian-Speaking World
}

\author{
Larisa Fialkova \\ University of Haifa \\ Haifa, Israel
}

\author{
Maria Yelenevskaya (1) \\ Technion - Israel Institute of Technology \\ Haifa, Israel
}

\section{Abstract}

The events of 2014 in Ukraine triggered a wave of discussions and narratives rewriting history and reexamining allegiances and cultural affinities. Material for the study was drawn from Facebook, blogs and internet discussion forums, folk humor disseminated online, personal correspondence and participant observation. This essay discusses how opinions are formed in the diaspora and how they are affected by different sources of information. The attitude to events in Ukraine has turned into a litmus test in personal relations, sometimes leading to a break up of friendships and family relations. Our analyses will disclose ambivalences in the perception of Ukrainian crisis in the diaspora. Those who support Ukraine do not necessarily come from that country or have cultural affinities with it and not all Ukrainian supporters identify with democratic values. Critics of the current Ukrainian government do not always support the actions of Putin's Russia. Among them there are also people from Ukraine and able to speak Ukrainian. Like many political conflicts this one fueled nationalism not only in the participating countries but also in the Russian-speaking diaspora.

\section{Introduction}

The conflict in Ukraine has triggered a clash in the narrative about the history of Russian-Ukrainian relations, the role of both nations in World War II, and interethnic relations - all being the heritage of Soviet policies. The Jewish theme, which is peripheral in the debates in Russia and Ukraine, is the core in the perception of the crisis in Israel. The revision of the historical narrative that evolved in the Soviet period has turned into a war of collective memories reflected in the personal narratives. Who is the victim? Who is the perpetrator and who is the liberator? The roles which are crucially important for identities keep changing from narrative to narrative and are challenged by the narrators and their audiences.

On the $23^{\text {rd }}$ of April 2014, a popular Israeli Russian-language news portal NEWSru.co.il published the following announcement:

В пятницу, 25 апреля, с 9:30 до 13:00 около посольства Российской Федерации в Тель-Авиве, расположенного по адресу улица а-Яркон, 120 , пройдет очередной митинг в поддержку Украины, против политики Кремля. 
[On Friday, April 25 a demonstration in support of Ukraine and against the Kremlin policy will take place from 9:30 to 13:00 in front of the Russian embassy in Tel Aviv, Ha-Yarkon St. 120.]

This demonstration was the fourth since the annexation of the Crimea by Russia. The organizers mobilized participants through Facebook. At the end of the announcement we found the following:

\begin{abstract}
Отметим, что 25 апреля, примерно в то же время, в Тель-Авиве будет проходить еще одна демонстрация - около посольства Украины под лозунгом 'против хунты и за юго-восток Украины' соберутся сторонники России.
\end{abstract}

[On April 25, approximately at the same time there will be another demonstration in Tel Aviv near the Ukrainian embassy under the slogan 'Against the junta and in support of South-Eastern Ukraine'.] [http://newsru.co.il/israel/23apr2014/meeting_104.html, 31 March 2015].

Notably, the address of the Ukrainian embassy was not mentioned. Was it by chance? The quoted announcement illustrates the rift which has formed between ex-Soviets due to the tragic events in Ukraine. Radical disagreement in the attitude to the conflict not only divided citizens of the two countries but also the multiethnic ex-Soviet diaspora whose members live across the world. Although almost a quarter of a century has passed since the demise of the Soviet Union, behavioral traits of the émigrés and their attitudes to host societies and to their country of origin have retained similarities. In addition, transnational ties of ex-Soviets remain strong. For these reasons, we will use the term ex-Soviets to characterize these groups. The notion of the ex-Soviet diaspora has been explored in Fialkova and Yelenevskaya 2005, Markowitz 1995 and Remennick 2002. A vivid illustration of the opposing attitudes to the Ukrainian conflict is numerous meetings and demonstrations held by immigrants from the former Soviet Union (FSU) in Europe (Germany, Latvia, Spain, Italy and Greece) and marches in the United States and Canada. Whether participants support Ukraine or Russia, anxiety about the fate of relatives and friends who still live in the areas where clashes and military actions took place often arises in speeches and posters. Demonstrators are also concerned about ideological differences which split families and destroy long-term friendships. Moreover, there are worries about the integrity of memorial places and family graves. Finally, political and economic repercussions of the situation are linked to life in the host countries with all the implications for the countries in general and in immigrant communities in particular. All of this makes the diaspora feel personally involved in the ongoing conflict. In this paper we will concentrate on the reaction to events in Ukraine among FSU immigrants in Israel. There are three reasons for this decision: First, Israel contains one of the biggest diasporas of ex-Soviets. Secondly, the theme of the Jewish role in the conflict, intensification of anti-Semitism and neo-Nazi movements both in Russia and Ukraine are salient to the way events are 


\section{Russian-Speaking World}

interpreted both by pro-Russian and pro-Ukrainian Russian-speaking Israelis. Finally, as FSU immigrants ourselves we are directly immersed in the narrative interpreting the situation and have been monitoring events and discussions about them since the end of 2013 .

\section{Immigration from the FSU to Israel: From the "Big Wave" to a Mere Trickle}

In order to better understand the involvement of Russian-speaking Israelis in the Ukrainian crisis, it is important to know some demographic data related to the immigrants to Israel from the countries of the FSU. Residents of Russia and Ukraine made up the majority of nearly one million immigrants from the countries of the FSU who settled in Israel in the 1990s. According to the Israeli demographer Tolts, in the 1990s, 230,500 came from the Russian Federation and 342,200 from Ukraine, which totals $29.9 \%$ and $31.5 \%$ respectively of the entire emigration wave from the FSU in this period [2001: 7]. In the first decade of the $21^{\text {st }}$ century immigration from the FSU shifted from a massive wave into a mere trickle. However, the political crisis triggered by the Maidan demonstrations at the end of 2013 and violent clashes in January-February 2014, the change of power in Ukraine on February $26-27^{\text {th }}$, the annexation of the Crimea by the Russian Federation in March 2014, and ongoing hostilities in southeastern Ukraine caused an increase in emigration from both countries involved in the conflict. According to the Jewish Agency for Israel, in 2014 immigration from the former Soviet Union rose by 50\% reaching 11,430 as compared with 7,610 in 2013. The most notable increase was in immigration from Ukraine, which grew by $190 \%$ to some 5,840 immigrants. 4,830 immigrants came from Russia, Belarus, and the Baltic states, as compared to 4,640 in 2013, [http://www.jewishagency.org/blog/1/article/31301, 15 June 2015]. (2) The growth of immigration from Ukraine continued in the first six months of 2015 and reached 3,583 (57\% more than for the same period in 2014) and immigration from Russia amounted to 3,146 (a 52\% increase as compared to the same months in 2014), [http://www.newsru.co.il/israel/13jul2015/aliya_115.html, 12 September 2015]. (3) It is important to note that many Russian-speaking Israelis have dual citizenship, enjoy the right to vote in their countries of origin and own property there. (4) As mentioned earlier, some immigrants who come from various FSU countries may have family and friends in Russia and Ukraine and regularly travel there on business and for vacations. Naturally, these people are concerned about events "in the old country." Notably, even among those who emigrated as little children, there are some who closely follow the events and participate in discussions expressing their ideological position and attitudes to events.

\section{Material and Method}

Material for this paper was drawn from various sources. We monitored Russian-Israeli internet portals and papers, four public discussion groups in Facebook (5) as well as personal Facebook pages. We chose pages (or "walls") of those Israelis of Russian or Ukrainian origin who are actively involved in the 
discussion of the conflict, known for their scholarly and media publications, and have a large number of Facebook friends who disseminate materials by posting their comments, by "liking" and by reposting ("sharing") articles on their own pages. As has been already shown in folkloric research, by their nature, Facebook posts are an "epistolary folklore phenomenon, a sub-form of the Internet memes which spreads by one click from wall to wall, forming a human chain from the posters" [Voolaid 2013: 74]. Notably, in the Facebook and LiveJournal discussions that we monitored, the participants commenting on the posts of Russian-speaking Israelis included residents of Russia and Ukraine, Belarus, the United States, Germany, the Czech Republic, and other countries, which confirms our view of this discourse as transnational and diasporic. Although it becomes clear from discussions that participants belong to various ethnicities of the FSU, the prevailing language is Russian, even in the posts of pro-Ukrainian supporters. Yet some messages are either completely or partially written in Ukrainian. Some authors alternate languages, depending on the subject and addressees of their posts. Moreover, some texts are in English and there are numerous cases of Russian-English code mixing. According to the political scientist, Volodymyr Kulyk, a similar use of languages is typical of Ukrainian online resources [2013: 73-74]. The use of language is crucial here, since hostilities in Ukraine were preceded and partially triggered by a "linguistic war" and attempts of the Ukrainian government that came to power after Victor Yanukovich was deposed to oust Russian from the public sphere. While collecting material online, we also kept ethnographic diaries, recording people's talk in public places and making notes of the conversations in which our interlocutors expressed their attitudes to the crisis as well as related concerns and emotions. We decided not to use interviews for this study because the topic is so sensitive that we feared the subjects would be reticent.

In our study of the online material we were interested to see what topics inspired commentaries, sharing and "“likes"”, and what media sources were linked to the discussants' posts. In Facebook, blogs and discussion forums users' exchange is akin to face-to-face communication in which participants exchange narratives. We wanted to see how the choice of vocabulary and the use of tropes contribute to solidarity of like-minded people and were used for "othering" opponents. Besides verbal material, we analyzed visuals, such as posters, photographs, cartoons and YouTube videos. We view these resources as visual narratives integrated into the verbal discourse. We noted that, in political debates, discussants often blame their opponents for choosing the "wrong" TV channel as a source of information. We would like to point out that neither of us watches political programs on television, yet some participants in the discussions we followed do and may have been influenced by the ideology of their preferred stations.

Having conducted content analysis of the posts in the Israeli Facebook groups, blogs and forums we monitored, we singled out 20 recurrent themes of discussion. However, the content of some themes overlaps, so that we reduced the key themes to 11 primary topics: 
The Crisis in Ukraine and the Split of Identity in the

\section{Russian-Speaking World}

1 Historic antecedents of the conflict ranging from Kievan Rus' to the post-Soviet relations between Russia and Ukraine;

2 Who is the aggressor and who is the victim?

3 Ethnic intolerance manifested in the conflict

4 Taking sides in the conflict and breaking friendships

5 The roles of Jews and Israelis in the conflict

6 Can a country build a democracy while glorifying Nazi collaborators at the same time?

7 Can Nazi collaborators serve as models for emulation for Jews?

8 Victory Day: Whose holiday is it?

9 Russia vs. Ukraine, Israel vs. Gaza: Is there similarity in the two conflicts?

10 Europe's attitude to the Russian-Ukrainian and Arab-Israeli conflicts

11 Are protests similar to Maidan possible in Israel?

Sensitivities of Taking Sides in the Conflict

Israel found itself in a difficult situation because in the last two decades both Russia and Ukraine have become its important economic partners. To a large extent, thanks to the contribution of immigrants from these two countries, visas were no longer necessary to come to the country, thereby dramatically increasing tourism in Israel. Joint ventures with Russian and Ukrainian partners were established and thrived, sister-city agreements were signed, theater and concert tours were organized, and exhibits were exchanged. Until recently, veteran Israelis seldom made any ethnic distinction between ex-Soviets coming from various countries of the FSU-all were dubbed "Russians". Moreover, immigrants themselves lived in symbiosis, speaking Russian, doing business and spending leisure time together. While the Russian language has become the third most spoken language of Israel, the use of Ukrainian remains limited. Snobbish attitudes to the Ukrainian language on the part of Russian speakers can be traced to the Soviet period when Russian was associated with global use, power and high culture, and Ukrainian was perceived as a regional and provincial language at best. Moreover, for many Israeli Jews of the older generation, it is still associated with anti-Semitic pogroms plaguing shtetls from the period of Bohdan Khmelnitsky in the 17th century until the Civil War of the 1918-1920. In addition, some witnessed atrocities by the Ukrainian police and armed units during the Nazi occupation during World War II [see Fialkova 2007: 109-11]. It is important to note that the Orange Revolution of November 2004 - January 2005, which did not go beyond demonstrations and strikes, did not trigger disagreements in the Israeli immigrant community. The violence that exploded on the Maidan in February 2014, the annexation of the Crimea, the tragic events in Odessa of May 2014, and the escalation of violence in Donbass divided the community as well as friends and families. A journalist reflecting on the roots of the divide reported:

Brothers Semion and Isaak Briman, who fought in World War II, could not imagine that their grandsons living in Israel, Shimon Briman and 
Simon Tsipis, would find themselves on different sides of the barricades because of Ukraine and Russia. Shimon, that's me, is a journalist and supports Ukraine, while Simon, an investigator of cyber terrorism, organizes demos with St. George's ribbons in Tel Aviv.

What are the roots of this break up? It may come from school years in Kharkov, where I was taught the Ukrainian language by the wonderful Raisa Fedoseevna Andriushchenko. Half of the Ukrainians in my class refused to study their mother tongue, so the teacher was preparing young Briman for the city Olympics in the Ukrainian language. Unlike me, Simon grew up in Sevastopol, in the city of "Russian seamen," which left an imprint of Soviet patriotism. My cousin, with his affinity with Russian culture, was ashamed even of the word "Ukraine," which symbolized everything that was second-rate for him. That's why he cheered Russian annexation of the Crimea. And I began to correct Israelis: Ani lo mi Rusia, ani mi Ukraina (Hebrew for "I am not from Russia, I'm from Ukraine") [Briman 2014].

This narrative reflects a typical situation as we know it from forum discussions and our participant observation. It clearly shows that ideological differences between the cousins are perceived as a family drama. The hierarchies of ethnicities built by the Soviet power were internalized by individuals. The author mentions ironically that although he is Jewish, he "likes" the Ukrainian language and was more proficient in it than most of his Ukrainian classmates. The towns where cousins grew up serve as markers of cultural affinity, because the influence of Ukrainian culture and popularity of the Ukrainian language differed from region to region. At the same time, as we see today, coming from one town does not guarantee staying on "the same side of the barricades"- the military metaphor often used in Russian. In conclusion, the author admits that despite these differences he would still meet his cousin for a mug of beer "although we are only second cousins, after all, we are brothers-Israelis." This concession prioritizes Israeliness over family ties, but the fact that a family divide becomes a topic of public discourse reveals that such divisions are a matter of concern for members of the community.

Even brief encounters among friends who have not seen each other for a long time often end in discussing events in Ukraine, which includes complaints that interpersonal relations with people in the home country, in Israel and other countries of the Russian-speaking diaspora are becoming complicated when there are differences in political views. Practices used to cope with the divide differ. We have observed cases when old friends stop seeing each other. When immigrants are not ready to sacrifice old friendships they agree not to mention events in Ukraine at all. Sometimes a request not to raise the topic of Ukraine is announced at the beginning of informal meetings or parties. Similarly, contact management can be observed on the Internet when bloggers or Facebook users declare "red lines" (a halt) to discussing issues related to Ukraine. Some ban or "de-friend" anyone who supports the other side, others are more tolerant but announce that they won't stand opposition on specific issues. Take, for example, comments by a historian and a pro-Ukrainian activist Mikhail Uritsky and one by 
The Crisis in Ukraine and the Split of Identity in the

\section{Russian-Speaking World}

the political left-wing activist Alla Shainskaia. Both follow upon the scandal that emerged after a TV journalist Daria Nenakhova appeared at a pro-Ukrainian demonstration wearing a tee shirt representing a controversial figure from Ukrainian history, Stepan Bandera.

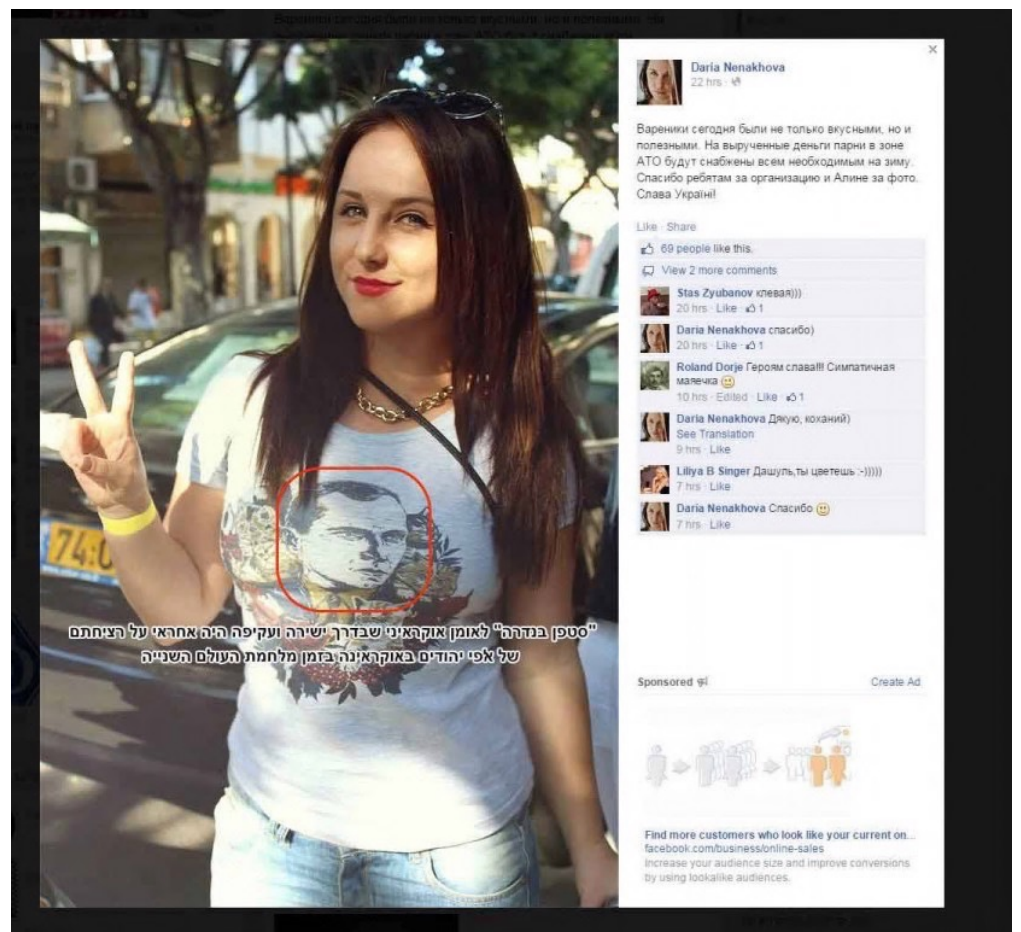

Journalist Daria Nenakhova wearing a T-shirt portraying S. Bandera surrounded by white fluffy cats.

Misha Uritsky, 31/10/2014 (848 Facebook friends) (6)

So it's like this. I have just come across a new disgusting attack targeting Daria Nenakhova, who was wearing a T-shirt portraying Bandera surrounded by kittens at a pro-Ukrainian meeting. Although this time there were no curses, humiliation or threats, the post was particularly nasty because the author claimed that Daria Nenakhova had a Ukrainian rather than a Jewish soul and so Israel was the wrong place for her (...) So far I have never removed people from my friend list, either on Facebook or in real life, for merely holding views differing from mine, even if I see them as deeply wrong and repulsive. Among my friends, including very close friends, there are errant "Colorado-beetles" who are defiantly pro-Russian. But if I see a single attack against Daria Nenakhova, the author of the post will be immediate banned. I am also appealing to all my friends, irrespective of whether they are pro-Russian 
or pro-Ukrainian: If you come across something like this in your friendlist, please de-friend them. (7)

(This post had 41 "likes" and was followed by 65 comments)

\section{Alla Shainskaia, 31/10/2014 (212 followers)}

I support both Mikhails wholeheartedly. Daria, thanks a lot. For your courage! Myself, I am used to humiliation and threats, and so I highly appreciate your civil courage. As far as Bendera is concerned, he is an ambivalent personality, like Bat'ko Makhno. I agree with the way Mikhail evaluates him.

Misha Uritsky, unfortunately, for the first time since I started using Facebook I have banned friends. I can no longer stand their pro-Putin propaganda and disgusting lies. I guess it's due to age. My nerves fail me. I cannot and do not want to remain friends with these people. I have never done this before, even not against people who have different views on our local conflict, naturally, with the exception of clear-cut "Nazis". The Ukrainian conflict has built up a red line and unconscious flair which I obey

(Six "likes").

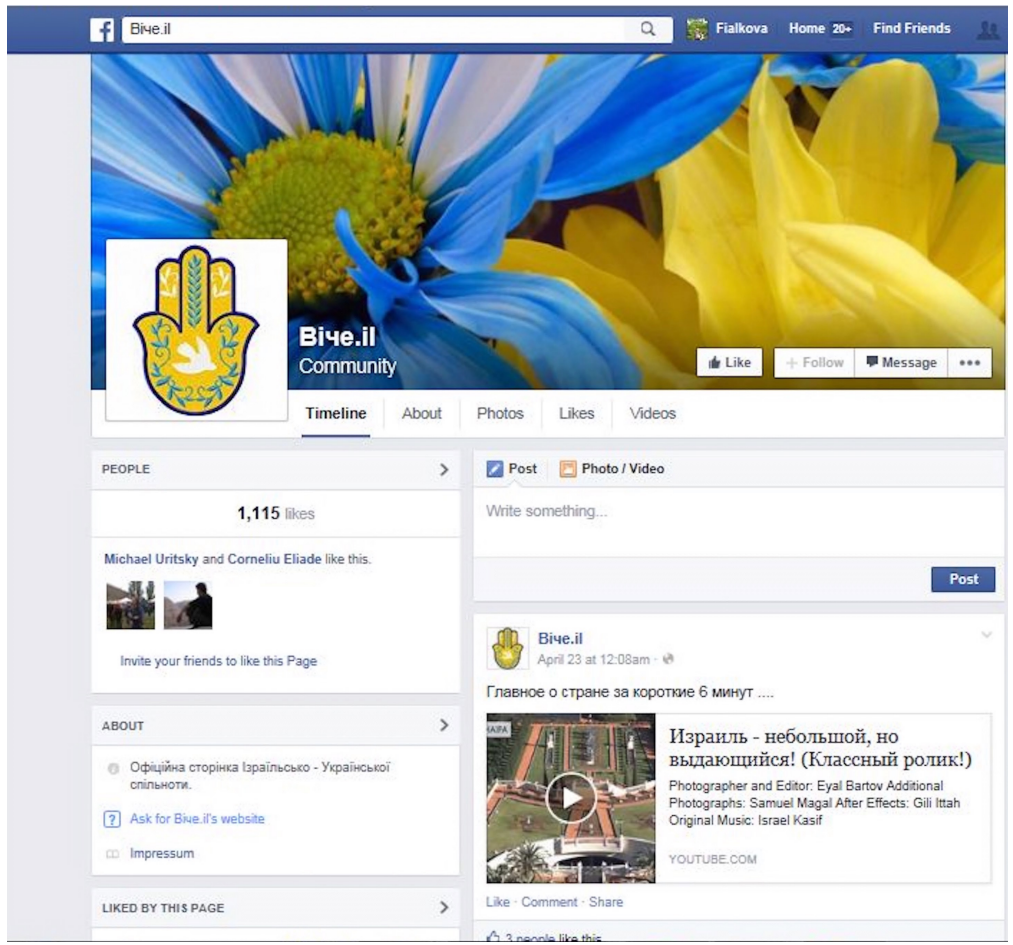

The public FB group Viche.il combines Israel's and Ukrainian symbols on its "wall". 
In online communication "de-friending" and banning contacts is similar to refusal to greet and shake hands in face-to-face communication. And an appeal to others to follow suit is reminiscent of ostracism. At the same time, Facebook users and bloggers practice appeals to their contacts to disseminate posts and information. For example, a member of the group Viche.il posted an appeal to Israelis:

...A special event: Sign to support Ukraine! If you are an Israeli citizen and support Ukraine, open this ad, mark it with "like" and in the comments write two words: Glory to Ukraine! (407 "likes" and 149 shares) [5, September 2015].

This and other similar posts go beyond friendly communication. We view them as propaganda of a particular position and agitation similar to speeches at demonstrations and meetings. The slogan "Glory to Ukraine" is contested in exchanges about the post and reflects two clashing narratives. One associates it with Ukrainian Nazi collaborationists, the other with Ukrainians' struggle against Victor Yanukovich's corrupt regime and as a challenge to Putin's policies in Ukraine. In the latter case, it becomes a symbol of freedom and affinity with European values. It is in this meaning that the slogan was used by the Facebook group Viche.il whose appeal to click "likes" and shares we have quoted. Both versions of the history of the slogan are widely represented in the electronic media - one tracing it back to the 1920 s, the other attributing it to the motto of Nazi collaborators, but neither is sufficiently documented, so both constitute part of the mythology.

Several issues are noteworthy in the passages quoted above. First, the reference to Facebook friends who are called Kolorady. Narratives about the Ukrainian conflict abound in pejorative words and expressions used by both sides. The name of a Colorado beetle has become a nickname for Russians and supporters of Russia in this conflict because the orange and brown stripes of St. George ribbon symbolizing Russia's military glory, which has recently become popular in Russia and its diaspora, has the same colors as the insect, a symbol of a stealthy and desctructive invader. Allusions to insects and animals is a wellknown folkloric and literary device used to dehumanize an opponent or an ethnic "other" [Belova 2005: 213-257; Fialkova \& Yelenevskaya 2007: 91-93; Hollingsworth 2001: 152-186].

An important motif in the quoted narratives is the claim of Daria Nenakhova's detractors that her soul is Ukrainian. The belief that aliens have no soul is prominent in Russian culture's perception of the "other." Svetlana Boym, for example, observes that in Dostoevsky's world, Germans, Jews, and Poles are deprived of the soul and this makes "a truly monstrous 'other' of the Russians [1994: 85]. Dale Pesmen, who conducted ethnographic research in Siberia in the 1990 s, came to the conclusion that among the many contexts that have woven into the meaning of "soul" nationalism remains strong. The soul is still conceived of such that Russian soul makes sense, but a Jewish, Turkish, Tatar, or Ukrainian soul does not sound right to Russians [Pesmen 2000: 14]. Clearly, Russian- 
speaking Israelis have internalized the perception of the importance of possessing a special soul, but in this narrative, it is Jews who are credited for being endowed with it. Another clash of mythical and bureaucratic models is that the right to be in Israel is determined by blood (having at least one Jewish grandparent) or by religion (Judaism). The question of soul is not raised in the discourse about citizenship. However, in the post by Misha Uritsky, the "soul" functions as a synonym of loyalty to one's people and substitutes for blood. People scandalized by Nenakhova's provocative tee shirt claimed that Israel was not the right place for her. Ironically, accusations of disloyalty were and are often addressed to Jews both in Russia and Ukraine by anti-Semites shouting "Clear out! Go to your precious country, off to Israel!"

The tee shirt which triggered indignation about Nenakhova's behavior portrayed Stepan Bandera surrounded by white kittens. "White and fluffy" is a popular phrase used in contemporary Russian to depict someone who presents no danger or threat. Stepan Bandera (1909-1959) was a Ukrainian nationalist, a controversial figure whose activities during World War II have been heatedly discussed in academic and folk historiography. Academic discourse strives for an unbiased evaluation of his struggle for Ukrainian independence, in which the end justified any means, including terrorism and collaboration with Nazi Germany [Ishchenko 2014; Kulyk 2013; Marples 2006; Narvselius 2012]. Folk historians, on the other hand, draw bits and pieces of Bandera's biography out of context and build up two conflicting narratives - one resembling the genre of hagiography and the other a demonic legend. In 2010, during the regime of President Victor Yushchenko, Bandera was posthumously awarded the title of "Hero of Ukraine," a decision which was condemned by the European Parliament as well as by Russian, Polish and Jewish organizations. In 2011, under the next president, the deposed Victor Yanukovich, the act was officially repealed, but a movement for its restoration began and is still ongoing. The popularity of the former or the latter narrative is determined by geography: Bandera is glorified in western Ukraine and condemned in southeastern regions. During the second Maidan protests that took place between November 2013 and February 2014 and in their aftermath, we observed an attempt to transform a regional icon into an all-Ukrainian hero, which led to a clash of popular historical narratives constantly manipulated by politicians. In popular parlance, the meaning of a "Banderite" has expanded and came to connote anyone who supports the current Ukrainian government or Ukraine's European orientation. Moreover, pro-Ukrainian Jews call themselves Judeo-Banderites. Since anti-Semitism was an important part of Bandera's ideology, this term is an oxymoron. For pro-Russian supporters a "Banderite" is equated with a neo-Nazi.

Returning to the nefarious tee shirt representing Bandera together with fluffy cats, the photograph of a smiling Nenakhova with a Tel Aviv street in the background was soon manipulated and, in one manipulated version, she appears next to mutilated and murdered infants, implying her support for the atrocities. This image appeared in the blog http://zvezdochettt.livejournal.com/298852.html on 8 May 2014 and was reposted on the same day on Facebook by an Israeli pro- 


\section{Russian-Speaking World}

Russian

activist

Evgeny

Kubantsev, https://www.facebook.com/gondolla.gonny?fref=ts.

In the comment by Alla Shainskaia, Bandera is also linked to another controversial figure in Ukrainian history, "Father Makhno," whose image created in literature and Soviet movies is associated with Jewish pogroms and violence against civilians. A fearless left-wing activist who consistently works on improving relations between Arabs and Jews in Israel by establishing dialogue, Shainskaia admits that she had never banned Facebook users insulting her for her views on the Arab-Israeli conflict. The link between hostilities in Eastern Ukraine and the Arab-Israeli clashes in Gaza is a recurrent theme and it arises both in the narratives of Russian-speaking Israelis and in those of their Facebook friends from the FSU.

Another narrative posted by Miriam Feyga Bunimovich, a pro-Ukrainian activist and an orthodox Jew, reveals how Facebook contacts are banned as a result of political disagreements and how political views are confused with ethnic belonging:

Miriam Feyga Bunimovich, 22/07/2014, (1397 friends)

- look where you click, otherwise you'll have to encounter something like this:

today I was on a bus and browsed Facebook on a small screen of my mobile. It suggested that I should join the group "Israel supports Ukraine". so I pressed a raised finger or a checkmark, I don't remember which. Later I get a message from a lady whose name is Natalia Belakovsky. "What is your goal in joining the group?" [she asked F \& Y] I got tense and ask: "Remind me which group I wanted to join. Support of Israel? " and she answers: "Israel for ukraine without banderites". and I think: Shit, here we are. This is what Facebook and my small screen concealed. And why wasn't I smart enough to say as neutrally as possible without going into detail that I had pressed a button by mistake. Instead, I wrote something, something I shouldn't have written. look what happened next.

- Nope. I am for Ukraine with Banderites. Facebook misinformed me. (I restrained myself and refrained from saying, yeah, to be more precise, I'm a "Judeo-Banderite".)

- I am simply a moderate person and reasonable too. I am not sure I wish to continue this conversation. Our routes diverge.

- It wasn't me who started this conversation. You wanted to join a closed group whose promo states under what circumstances one can apply. If I had found out from your page that you were fit to be a potential member, there wouldn't have been any questions and you would have been accepted wholeheartedly. I'm not talking to you. I'm just stating facts. For Jews, Banderites are murderers. They are responsible for killing 1,500,000 Jews, from (19)40 to (19) 45. This is a 
quarter of all Holocaust victims. If you are for Banderites, then a Jew who is normal would ask how come you, a moderate Banderite, happen to be in Israel. Is your moderation in that you don't go as far as killing Jews but just share Banderites' views? You don't have to answer. I don't need your answer. I am just asking myself: How come this Banderite trash managed to creep into Israel. I hope you will move to this lousy Banderite Ukraine. Yours are already in power there.

after this abuse the subj [slang for subject] banned me. I wonder how come people have time and strength for nastiness. I for one, don't always have enough resources to do good, as to disgusting stuff, it's a shame to waste the time, but some others let's go on living and create positive things (smile) (44 "likes" and 13 comments)

Although Miriam Feyga's behavior was not as provocative as Daria Nenakhova's, the response was the same. Affinity with Ukrainian nationalists was interpreted as affiliation with neo-Nazis, the current Ukrainian government was perceived as Banderite, and Miriam Feyga was rejected as a member of the ingroup, becoming a despised "other" who did not belong and would be better off in Ukraine than in Israel. The irony is that Miriam Feyga is not only Jewish and religious, but is a Zionist convinced that Israel is her home.

Thus far we have quoted only pro-Ukrainian activists, but it would be wrong to think that their pro-Russian opponents have kept a low profile. They have also founded Facebook groups, such as Izrail' za Ukrainu bez banderovtsev [Israel for Ukraine without Bandera], [https://www.facebook.com/groups/ukr.bez.banderovcev/, 12 September 2015] and Sut' vremeni , Izrail' (The gist of Time, Israel), [https://www.facebook.com/groups/816878271675184/, 12 September 2015]. They also demonstrate, protesting against bloodshed in Donbass. Some of these actions were organized in cooperation with Russian and pro-Russian Ukrainian NGOs. For example, the action Natsizm: proshloe $i$ nastoiaschee [Nazism: The Past and the Present] commemorating victims of UPA (Ukrainian Insurgent Army) during the Great Patriotic War and in Donbass took place during the latest hostilities in Donbass. It was initiated by Israeli human rights activists in cooperation with the NGO Materi Donbassa [Donbass Mothers]. Notably, the action took place in Jerusalem in front of the Holocaust Museum, [http://nsn.fm/in-the-world/pamyat-zhertv-natsistov-i-neofashistov-pochtili-v-

izraile.php, 12 September 2015]. The theme of the neo-Nazi revival in Ukraine and the role of Ukrainian collaborators in the Holocaust was the hottest theme in the discourse of pro-Russian activists, in particular, in the months leading up to the $70^{\text {th }}$ anniversary of Victory Day. As the most important and widely celebrated day in the yearly calendar in Russia, it has a special meaning for Russian-speaking Israelis. Before the mass immigration from the FSU in the 1990s, this day was ignored in Israel. Jews had been perceived as passive victims. But immigrants from the FSU saw the role of their fathers and grandfathers who fought on the 


\section{Russian-Speaking World}

fronts, toiled in the rear and won the victory in a different light. Thanks to the efforts of the World War II veteran organizations and some Russian-speaking Israeli politicians, the attitude of the Israeli public gradually changed and in 2005 Victory Day became an official holiday in Israel [Yelenevskaya 2009; Fialkova, and Yelenevskaya 2013: 172-173]. In 2015, the preparation for the annual marches and memorial meetings in honor of the victory was tainted with angry arguments as to whose victory it was: Russian or Ukrainian. Like in the past 10 years, in 2015 we, in Haifa, participated in the memorial march devoted to Victory Day. While the number of veterans wearing their orders and medals dwindled as compared to previous years, their place was taken by "children of war," who are already in their late 70-s and 80-s. Furthermore, in 2015, there were noticeably more young people and parents with children than in past celebrations. But the crowd was no longer united. A lot of participants, including children, were wearing St. George ribbons, mentioned earlier. Some carried Russian Federation flags and the flags of the self-proclaimed republics of Donetsk and Lugansk. We witnessed people from the crowd who stopped to be photographed with these flags in the background. However, not everybody was pleased by this situation. At the end of the official ceremony an elderly Russian-speaking pro-Ukrainian activist tried to seize one of these flags shouting: "No politics here!" The ribbons with the colors of the Ukrainian flag were few but during the ceremony we noticed a group of young Ukrainian speakers standing near us. One of the young men was wearing an embroidered black-and-red Ukrainian shirt. Although these youngsters chose to attend the event, they talked about it with obvious contempt.

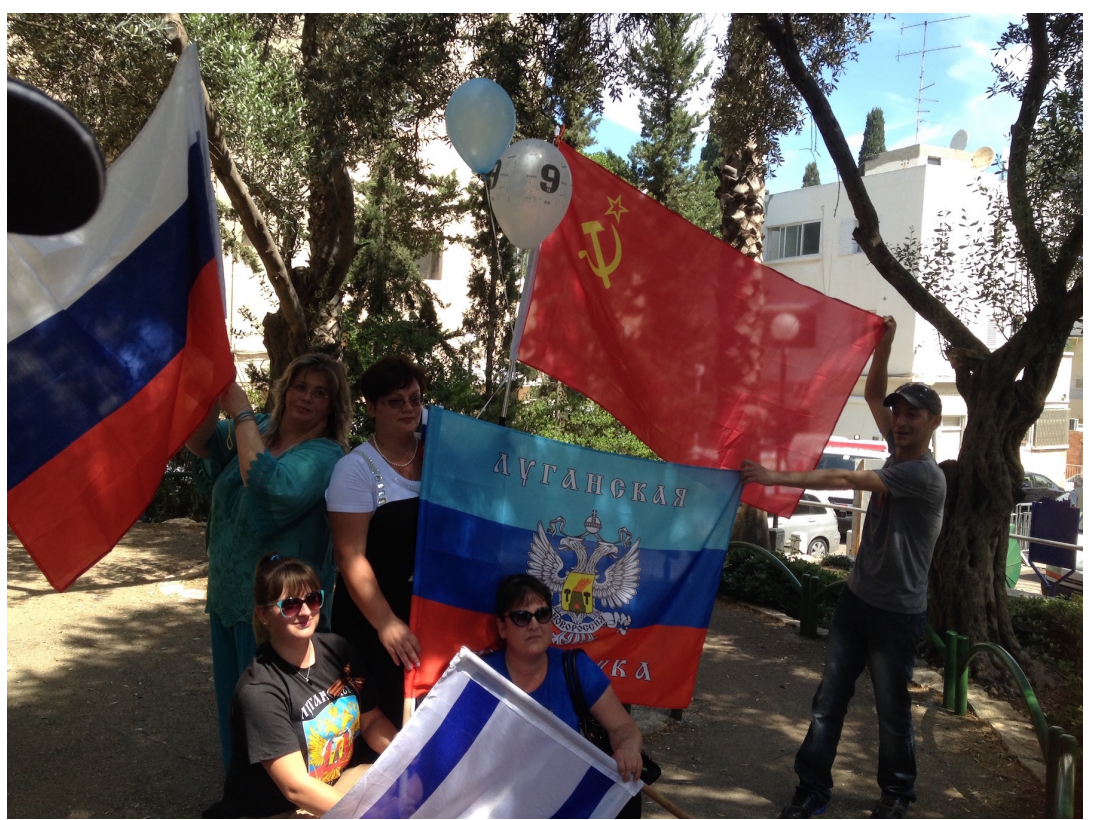

Victory Day in Haifa 2015. Participants of the march posing in front of four flags - Soviet, Israeli, Russian and the self-proclaimed Lugansk Republic.

FOLKLORICA 2015, Vol. XIX 
Nevertheless, the situation is complicated, so that some of the Facebook users and bloggers whose sites we monitored do not support either side wholeheartedly. They are less concerned with political goals and ideological positions than with death of civilians and senseless destruction of cities and villages. They criticize the propaganda of hatred and violence, as well as corruption of the elites on both sides.

Alek Epstein, 23 February 2014, (630 Facebook friends) Here is a question for my friends from Kiev, but not only for them: Why did almost every extremely samostiinyi deputy (speaker) who defends European values by fighting against the use of the Russian language and who insists on the demolition of monuments to Lenin start a career as the head of the agitation and propaganda division of the regional Komsomol organization?

(5 "likes")

Note that like in many other posts and informal conversations, the Ukrainian insertion samostiiynyi is used by Russian speakers ironically. This adjective denotes a country's independence but is primarily applied in talk about Ukraine's independence and individuals supporting it. Stating that many current Ukrainian politicians used to serve the Soviet power delegitimizes them as reformers and honest Ukrainian patriots. A quarter of a century after the demise of the USSR communist functionaries are still disliked and distrusted.

Even stronger the condemnation of corruption in the ranks of the Ukrainian elite is expressed by the journalist and blogger Anton Nossik. A resident of Moscow, he used to live in Israel in the 1990s and has double Russian-Israeli citizenship. He maintains contacts with Russian-speaking Israelis and occasionally publishes in the Russian-language media in Israel.

Anton Nossik, 12 February 2015, http://dolboeb.livejournal.com/2771279.html

...Recently a [Ukrainian] journalist was sentenced for treason because he declared that he didn't want to be sent to the Debaltseve pocket without clothes, food and ammunition. But there was no punishment for those who had stolen and sold defense resources of the country. And this is the reason why they cannot arm, dress or feed new recruits. They yell "moskaliaku na giliaku" [Ukrainian: Send the Muscovite to the gallows] but no tycoons or bureaucrat who became filthily rich by stealing army property is to be found on the giliaka (...)

P.S. I can well imagine the response I'll get to this post. How I sold myself to the Kremlin and to Putin, what a zhidokatsapskii moskal' [Ukrainian/Russian: "Judeo-Russian Muscovite] I am, and you will proudly de-friend me. I can't do anything about it, but I won't be too upset about it either. I did not write this post either for proud vatniki [Russian, cotton-wool jackets] or for ukropy [dill], but for thinking 


\section{Russian-Speaking World}

individuals. Judging by the comments, there are quite a few of them among my Russian and Ukrainian readers. They can't help realizing that in a deadly skirmish of one sovok [Russian: dust-pan] with another, the winner will always be the worst of them. The only effective way of getting rid of a sovok is to squeeze it out of your own system drop by drop. No American weapons can be of any help in this. (1,037 comments)

Nossik was right in foreseeing a burst of anger among some of his readers. At the same time, others, including Ukrainian residents, supported his viewpoint, expressing confidence that arms sold to Ukraine would not help the Ukrainian army. Note that like Alek Epstein, Anton Nossik refers to the Soviet past, which is still deeply ingrained not only in the elites but in the general public as well. The coinage of the slang word sovok was based on the partial paronymy of "Soviet" and "dust-pan." It is still widely used in the formal and informal discourse and has produced several derivatives, such as sovki and sovkovyi. Proposing that everyone should get rid of a Soviet-like mentality, Nossik alludes to Anton Chekhov, who admitted that he was squeezing the slave out of his system throughout his life. Thus sovok is made synonymous with a slave-like mentality.

In his post Nossik makes use of pejorative ethnonyms that have become pervasive in the discourse of the Russian-Ukrainian conflict. While moskal' and katsap have been used as ethnic slurs for a long time, vatnik and ukrop, standing for pro-Russian and pro-Ukrainian supporters respectively, are innovations which have gained popularity in the last two or three years. Note that zhidokatsapskii moskal' is a counterpart of the term zhidobanderovets that we mentioned above. Both are used as slurs but also as ironic and sometimes proud self-identification markers.

The two posts that follow also refer to the Soviet past of the readers. Their authors are appalled by the propaganda of violence and ethnic intolerance that replaced the utopian friendship among the Soviet peoples.
Alek Epstein, 13 July 2014,
The Ukrainian Minister of the Interior, Comrade Avakov, completes the summary of his ideas by saying: "They should be killed like mad dogs: [https://www.facebook.com/arsen.avakov.1/posts/648366948586748]. That Comrade Avakov is Comrade Vyshinsky's loyal disciple is his own problem and only his. Even if he doesn't understand this... But when 1,800 people share this human-hating horror and another 8,100 "like" it, this is real trouble. Unfortunately, they failed to "remain human"... [http://www.svoboda.org/content/article/25373012.html] (6 "likes", 3 shares).

The noun "comrade" placed before Arsen Avakov's name implies that his speech is grounded in the Soviet tradition. These ties are reinforced by comparing him to the ruthless state prosecutor Andrei Vysinskii, a notorious figure and active participant of Stalin's purges. The author of the post emphasizes that Avakov's 
words fell into fertile ground aggravating ethnic hatred. When appeals to kill ethnic "others" are pronounced by politicians, they may be interpreted by some members of the lay public as instructions for action. The persuasive power of the Ukrainian politician's words increases because of the identification of the "others" with "mad dogs," another instance of dehumanization shown earlier.

The Russian-Ukrainian conflict also has been the source of numerous rhymes, poems, cartoons and video clips. Some of these remain anonymous; the authors of others are known and widely discussed on the internet. A case in point is a young Ukrainian computer expert, Anastasia Dmytruk, who writes patriotic verses in Russian and Ukrainian and whose xenophobic song "We will never ever be brothers" became a YouTube and Facebook hit. Russian-speaking Israelis who were supporters of Ukraine included her poems in the program of the cultural event "Ukraine in poetry and music" held in March 2015 at the Russian library of Jerusalem, known as an important cultural community center. This event was among actions by immigrants in support of Ukraine. [http://www.newswe.com/index.php?go=Pages\&in=view\&id=8001, $\quad 15$ September 2015]

We find Dmytruk's song highly controversial. Full of passion and emotions, it seems to be a sincere expression of the author's feelings, but its overwhelming motifs are adulation of the in-group and unconcealed hatred for Russians. Adding to the repertoire of zoological metaphors used in the discourse about the conflict, Dmytruk refers to Russians as rats who will choke on their envy and wash themselves in their own blood. The whole song is based on juxtapositions generalizing the author's vision of the two nations. Some are explicit (huge great, chained - free, blind - fearless eyes, hiding- looking snipers in the face, ruled by the czar - democracy), while others are implicit. In more subdued portions, Russians emerge as lacking spirit and will (hesitant, silent, obedient to directives) while Ukrainians are free and rebellious (hot blooded, dangerous even when unarmed, [burning] fires of rebellion). The text of the song and the YouTube clip had multiple shares in Facebook and were often followed by comments demonstrating the polarizing opinions of the audience. Some were praising the author for capturing the mood and feelings of Ukrainians and encouraging her to continue writing in the same spirit. Others expressed anger at the author for provoking animosities. There were also comments trying to convince Dmytruk that her vision of the social victories won by the Ukrainian people was erroneous as well as furious remarks rejecting her right to speak for the whole nation. The song gave rise to numerous pastiches. All of them formed a dialogue with the original text and like the comments on posts and blogs demonstrated a diversity of opinions. Several of these texts mirrored the xenophobic attitude of the original but demonized Ukrainians, not Russians; others claimed that brotherhood between the two nations would prevail [see the text of the song and comments at https://www.facebook.com/siadmytruk/posts/605508626186444, 15 September 2015]. Among Dmytruk's critics was a popular Israeli "political technologist" (8), online journalist, and blogger, David Aidelman.

David Aidelman, 6 April 2014, (3,447 Facebook friends) 


\section{Russian-Speaking World}

The Russophobic song "We'll never be brothers" is disseminated on the Internet as an "anthem of free peoples"...

We will never ever be brothers,

Not by motherland, not by mothers.

Your souls aren't free, they're crippling -

We won't even become step-siblings. (9)

I honestly don't quite understand what makes Ukrainians feel they are freer than residents of Russia?! What do they measure? If we look at the extent of contemporary slavery, that is flesh peddling, then Ukrainians are ahead of all ex-Soviet republics. The majority of prostitutes operating in Europe, North America and the Middle East are exported from Ukraine. If we consider economic freedom, then compared to Ukraine, even in Russia economy is more liberal.

In your home "silence is golden"

And we burn Molotov cocktails...

First, Molotov cocktails are not burned. One has to light the fuse and throw the bottle aiming at the target. The glass breaks, flammable liquid pours out and the fuse sets it aflame.

In fact, the proverb "silence is golden", (silentium aurum est) can be traced back to Ancient Rome. Like most proverbs, it is a shortened version of partially forgotten proverbs: [in this case] "Speech is silver, but silence is golden"

The Russian version of "silence is golden" was derived from Latin; its Japanese counterpart is the proverb "silence is flowers". Then there are proverbs of other peoples ["speech is silver, silence is golden" [authors' note: portion in quotations originally in English].

Finally, it's the first time that I hear that throwing Molotov cocktails could be an indicator of freedom. The next thing would be for them to measure freedom by the level of street rape...

(115 "likes" and 39 shares)

Aidelman questions the author's understanding of freedom. His skepticism addresses such different aspects of freedom as national economy and civilian order. He implies that Ukrainians do not have much to boast about today and undermines the poetic value of the text. Unlike many other Facebook commentators about the song, the tone of his post is impassionate but ironic. The number of "likes" and shares of his post, as well as the engagement in the discussion on Dmytruk's own Facebook page by participants from Russia, Ukraine, and the near- and far-abroad (over 700 comments) demonstrates that whatever the merits of the text, it did not leave the public indifferent; moreover, the song contributed to the folklorization of the conflict.

On the September 16, 2015, passions were again ignited when the Ukrainian president Petro Poroshenko signed a decree banning more than 400 individuals and 90 organizations presenting a "threat to national interests" or that promote "terrorist activities" from entering Ukraine for a year [http://urainform.com/ru/politics/2015/09/16/poroshenko-podpisal-ukaz-o-vvedenii- 
sanktsij-protiv-rossii, 16 September 2015]. Among those blacklisted were public figures and journalists from Russia and other countries, including six Russianspeaking Israelis. Banning journalists for reporting on and filming events in Ukraine or participating as independent observers in the referendum in the Crimea and elections in the self-proclaimed republics in Donbass resulted in severe criticism for curtailing freedom of speech [e.g. , articles in the Guardian http://www.theguardian.com/world/2015/sep/16/ukraine-president-bansjournalists-from-country, in the Sofia Globe http://sofiaglobe.com/2015/09/17/ukraines-ban-of-foreign-journalists-ignitesinternational-ire/, and a statement by the Committee to Protect Journalists, [https://www.cpj.org/2015/09/ukraine-bans-41-international-journalists-andblog.php , 20 September 2015]. Some of the journalists who found themselves on the list responded publicly, stating that they saw it as their duty to remain neutral and impartial in their reports. Among them were Israeli journalists Max Lurie and Alexander Ronkin. David Aidelman, quoted earlier, also made statements to the press and posted his comments on Facebook. Because these texts are quite long, we will quote only excerpts from them.

\section{David Aidelman, 17 September 2015}

Today Poroshenko signed a decree on sanctions against individuals and legal entities. Two lists approved by the National Security and Defence Council. (...)

I am number 9 there. The reason is that all of us allegedly observed elections in the Donetsk People's Republic and Lugansk People's Republic. I personally have never been to Donetsk or Lugansk. It is not only that I wasn't there during the elections, I have never been there at all (...)

Among foreign journalists subjected to sanctions are 3 (three !!!) pennames. They have banned pen-names from entering the country! Glaziev appears on the list twice. Has he been banned twice? The second one is probably ban checking [This is an allusion to "dead checking", in military slang this expression denotes an additional shot into the head to verify that the victim is dead].

In addition, under number 307 of the list they put Mozgovoi, Oleksii Borisovich. Do they fear invasion from the other world?! To be honest, the deceased was not a model Banderite. But does he deserve to be banned?

(99 "likes", 35 comments, 5 shares)

Putting on the list two journalists reported missing, probably kidnapped by Islamists in Syria, and the careless mistakes noted by Aidelman caused major embarrassment for the Ukrainian president. He apologized and ordered to removal British journalists from the list, but this step did not prevent angry discussion in the press and on the Internet. In Facebook comments we see comparisons of Ukrainian politics with the Soviet politics of lies, references to Shtirlits, the legendary protagonist of the cult movie "Seventeen Moments of Spring," and 


\section{Russian-Speaking World}

conspiracy theories attempting to explain away the carelessness in preparing the list. All of this suggests that publication of the latest Ukrainian blacklist is being folklorized as well, like the conflict itself.

The Jerusalem Journalist Association condemned the Ukrainian government for sanctions against journalists, and the Russian-language Israeli portal IzRus sent an inquiry to Poroshenko demanding explanations of what crimes journalists and political "technologists" committed towards the Ukrainian state [http://izrus.co.il/obshina/article/2015-09-18/28856.html, 19 September 2015]. In order to draw maximum attention to the censorship and curtailing of freedom of speech by the Ukrainian government, David Aidelman appealed to his Facebook friends to repost the text of the inquiry and launch it as a flash mob. Apparently, he failed to attain his goal, because 4 days later this post collected only 31 "likes" and 44 shares.

There is no agreement among Russian-speaking journalists about the latest Ukrainian blacklist. Thus one of them, Yakov Shaus, published an article on the Russian-language Internet portal zahav.ru, in which he blames his colleagues for serving Putin's regime [http://mnenia.zahav.ru/Articles/6617/poroshenko, 24 September 2015]. As expected, the article immediately ignited a new round of discussion about who is "right" and who is "wrong" in the conflict on the portal where it was published as well as on Facebook.

\section{The Jokelore of the Conflict}

During periods of conflicts and hostilities, anger and frustration at the situation are often released by folk humor. Jokes, cartoons, rhymes, manipulated photographs, video clips and multi-media ensembles about the Ukrainian situation originated in Ukraine and Russia as well as in the diaspora. These pieces circulated in different media, but like most humor today, they are primarily disseminated digitally and become transnational. Some of the Facebook and blog posts begin with expressions such as: "I heard this on the radio..."; "Read what a friend from Gorlovka sent me..."; "I am forwarding what I have just got by email..." and so on. Our sample of jokes, rhymes and visuals cannot be simply divided into pro- or anti-Russian/Ukrainian; some are anti-corruption; others target business elites in both countries; still others shift the focus from RussianUkrainian relations to the political dilemmas of the Middle East.

We will limit our discussion to the jokes related to the topics discussed thus far and outlined as central themes in the Internet discourse on the conflict.

- Беня, а шо там такое на Украине?

- Россия с Америкой воюет.

- И шо, как там дела?

- Ну Россия потеряла таки тысячи солдат, сотни танков.

- А у американцев шо?

- Таки не поверишь, они вообще на войну не явились.

[- Benia, what's going on in Ukraine? 
- Russia is at war with America.

- And how are they doing?

- Well, Russia has already lost thousands of soldiers and hundreds of tanks.

- And how about Americans?

- You won't believe it, but they simply didn't show up for the war.]

[sent by e-mail to Maria by a Russian immigrant to the U.S.A.]

Direct Russian involvement in the hostilities in Ukraine and the deterioration of American relations with Russia are a frequent topic of both formal and informal discourse related to the Ukrainian situation. While Americans are often blamed by lay people in Russia for provoking the conflict, this joke shows events in a different perspective. It is left for the addressee to decide whether it is a noble or a shameful position to remain uninvolved. Many of the jokes related to the conflict and circulating on the Internet are passionately discussed and often result in a completely different interpretation in the posts of Russian and Ukrainian supporters.

Punning is highly appreciated by Russian-speaking jokers. The effect of the pun is strongest when the minimal modification on the phonological or morphological levels leads to a dramatic change in meaning and captures social and political realities. The best known pun associated with the annexation of the Crimea Крым наш - Нам крым [The Crimea is ours - We are gonna be dead meat] originated in Russia, but is well known in Israel. One of us overheard another joke devoted to the same event in a shop in Haifa. Like the previous pun, it presents the annexation of the Crimea as a trap for Russia:

Россия сделала себе крымацию.

[Russia has Crimated herself.] (a pun on кремация [cremation])

[https://www.facebook.com/david.aidelman?fref $=$ ts, last accessed 20

September 2015]

In Jewish jokes self-adulation is often intricately mixed with selfdeprecation. Both of these motifs are implied in the following two jokes posted on Facebook by David Aidelman shortly after the annexation of the Crimea:

- Смотри-ка, Рабинович грустный какой-то?

- Еще бы! Полгода назад, послушав Януковича о вступлении в

Европу, он, за немалые деньги, срочно купил украинское

гражданство и домик в Крыму... А позавчера ему снова радостно

вручили российский паспорт!!!!

[- Look at Rabinovich. Doesn't he look sad?

- Sure he does. Half a year ago he heard Yanukovich talk about joining Europe, so he paid a hefty sum for the Ukrainian citizenship and bought a cottage in the Crimea.... And the day before yesterday he was ceremoniously handed a Russian passport again!!!!] 


\section{Russian-Speaking World}

(58 "likes", 4 shares)

Человек обращает к Путину и говорит: «Владимир Владимирович, Вы, прежде чем решать вопросы с Крымом, советовались с Рабиновичем?»

— «С каким Рабиновичем?»

— «Да с любым!»

[- Someone says addressing Putin:

- Vladimir Vladimirovich, have you consulted Rabinovich before deciding what to do with the Crimea?

- Which Rabinovich?

- Any one will do!

(5 "likes")

Rabinovich was the protagonist of most of the Soviet Jewish jokes, whether they were told by Jews or by anti-Semites (see Shturman and Tiktin 1987: 485528). Attempts to outsmart everyone but falling victim to one's own slyness is also a well-established motif. The joke asking Putin whether he had consulted Rabinovichis popular on the Internet and can be found on several humor hubs such as http://anekdot.ru, https://anekdot.d3.ru, http://sarcasm.zone/anekdoty/119731. The person credited with launching this joke on the Internet is the Russian TV journalist Vladimir Pozner [http://pozneronline.ru/2015/04/10968/, 22 September 2015]. He used it as a gambit for a serious conversation with his audience about political events in Russia and Ukraine, France and Israel. David Aidelman linked the program to his post but he also placed the joke as a separate text, thus increasing its visibility.

Like in many other late Soviet and post-Soviet jokes, Lenin, Stalin and other Soviet leaders are summoned to judge current political events. The following joke, also posted by David Aidelman on Facebook, uses the title of an article by Joseph Stalin to juxtapose it with the punch line deriding failures in Ukrainian policies:

Чертенок в аду видит, что Сталин чего-то пишет, опираясь на край котла.

- Чего пишешь, дядя Иосиф?

- Вторую работу по украинскому вопросу...

- Как называлась первая?

— «Головокружение от успехов»...

- А эта как будет называться?

- Охренение от неудач...

[A little devil in hell notices that Stalin is writing something, leaning on the edge of the cauldron.

- What are you writing, Uncle Joseph?

- A second essay on the Ukrainian problem...

- What was the title of the first one? 
— "Dizzy with Success"...

- How will you entitle this one?

— "Going nuts after failures"...]

(36 "likes", 9 shares)

Financial problems related to Russia's sale of natural gas to Ukraine were often called a "gas war" in the media. Jokes related to this topic had been documented before the beginning of the military conflict and became popular again in 2014. For example, Larisa Fialkova received the following example, in Ukrainian and from a Ukrainian immigrant to the United States:

Україна нічогоне винна Росії за газ, бо він на території України просто заблукав...

[Ukraine doesn't owe Russia anything for gas that simply got lost on Ukrainian territory.]

An almost identical text, but in Russian, and purported to be a quotation from the Ukrainian prime minister Yatseniuk's speech, was posted by a Ukrainian user of Twitter and had 679 "retweets." Some took the joke at face value and praised Yatseniuk; others cursed him just as seriously. In many of the retweets there were quips, developing the theme of the quip and attempting to undermine either the Russian or the Ukrainian side [https://twitter.com/schnaps_ua/status/505428270230540288, 22 September 2015].

As mentioned earlier, deriding a Ukrainian accent, intonation and word choice is an old theme of in Russian language jokes. As might be expected, the theme again gained popularity at the time of the conflict.

- Скажите, как будет по-украински синхрофазотрон?

- Шо?

— Боже, какой прекрасный лаконичный язык!

[-What's the Ukrainian for synchrophasotron?

- Hwhat? [imitation of a Ukrainian and south-Russian pronunciation of

"what"]

- Jeez, what a wonderful and laconic language!]

(posted on Facebook by Aidelman, 65 "likes", 19 comments, 6 shares)

The synchrophasotron was a synchrotron particle accelerator designed by the Soviet physicist Vladimir Veksler and operated by Soviet researchers from 1957 to 2003. The pride of Soviet science, it was not only an extremely sophisticated device, but a difficult word to pronounce even for native Russian speakers. As a result, it was used in a variety of "stupidity" jokes, including those deriding underdeveloped language abilities. Notably, in some of the comments to 


\section{Russian-Speaking World}

David Aidelman's joke, we find an ethnic slur also formulated as a boomerang question-answer:

— А как будет синхрофазотрон по-русски?

— Хреновина

[- And what is the Russian for synchrophasotron?

- Some sort of bullshit stuff.]

Other pervasive motifs in the humor about Ukrainian politics are corruption and squabbles among members of the political elite. This theme was picked up by an online Israeli edition «Бесэдер? Для тех, кому еще смешно» Beseder [okay in Hebrew]? For those who are still amused. While so far we have cited texts that originated outside Israel but were disseminatedby those who live in Israel, the humor published in Beseder is written by Russian-speaking Israeli humorists. Stylized as a newspaper preoccupied with political reports, Beseder amuses readers by its instant response to the latest political news. Readers are encouraged to "tweet" and "share" texts and leave comments. Some do, posting their own quips in the process.

\section{Петя и банк}

После того, как банк Игоря Коломойского блокировал счета Петра Порошенко, президенту Украины стало не на что купить даже Раду икабинет министров....

[Petia and the Bank

After the bank owned by Igor Kolomoiskii blocked Petr Poroshenko's account, the Ukrainian president cannot afford even to bribe the Rada [Parliament] and the Cabinet of Ministers.

[http://beseder.ru/news/entryid/225, 10 September, 2015]

The title of this jocular report is an allusion to Sergey Prokofiev's symphonic tale "Peter and the Wolf". The Ukrainian president's first name Petro is Peter. President Poroshenko emerges in this humorous text as totally dependent on the notorious Ukrainian tycoon Kolomoiskiy, who is heavily involved in Ukrainian politics. In the structure of this text the business man implicitly becomes the wolf, the prototypical folkloric predator. The text derides the president's weakness and dependence on problematic personalities and also hints at the overwhelming corruption in the upper echelons of power where the Parliament and the cabinet of Ministers have to be bribed.

Each time a new round of restrictions was announced, the various sanctions imposed by the participants of the conflict on each other's nations have been targeted by Beseder. For example:

Как стало известно российскому изданию «Вечерняя Правда» в ответ на санкции Евросоюза, Госдума решила внести в Черный 
список европейские санкции. В ответ европейские парламентарии уже пригрозили наложить санкции на российский Черный список.

[Journalists of the Russian newspaper "Evening Truth" have found out that in response to European Union's sanctions State Duma (Russian Parliament) decided to blacklist European sanctions. In their turn European parliamentarians threaten to sanction the Russian blacklist. [http://beseder.ru/right-news/entryid/219, 10 September, 2015]

The duel of sanctions is presented as ineffective and pointless, a mere juggling of empty threats.

Bringing together realities of the immigrants' native countries and Israel is among the favorite techniques of Beseder's authors. The emerging world of the text mixes familiar characters and scripts thus encouraging us to see the familiar in a new perspective.

Инструкторы из Израиля приступили к обучению пограничников из Украины. Уже в первые дни на российско-украинской границе задержано 175 боевиков ХАМАСа и 12 тысяч суданских нелегалов.

[Israel's instructors began training Ukrainian border control servicemen. Already in the first days 175 HAMAS militants and 12,000 Sudanese illegal immigrants were rounded up on the Russian-Ukrainian border. [http://beseder.ru/news/entryid/372, 10 September, 2015]

Israelis were implicated several times as participants in the hostilities in southeastern Ukraine by people on both sides of the conflict. But in the quoted text the focus is not really on Ukraine but on the everyday practices of Israeli border police and their efforts to protect the country from Islamic militants and illegal immigrants. Their acts are often criticized in other countries for exaggerated vigilance.

Like other Russian-language editions, Beseder regularly "covers" events in Ukraine and Russia. Our search of its two-year long archive for the key word "Ukraine" yielded 150 relevant results. However, the editors realize the sensitivity of the situation and the possible repercussions of too deep an involvement by Israel in the conflict. The text we quote below is self-ironic. Its title is an allusion to Taras Shevchenko's «Реве та стогне Дніпр широкий» [The mighty Dnieper roars and bellows, http://www.dnipro-ukr.com.ua/scenariy-5864.html, 10 September 2015] and can be interpreted as a warning to the politicized former compatriots in Israel:

Реве та стогне Бен-Йегуда

Сегодня в городах Израиля пройдут демонстрации в поддержку

Украины. Митингующие подготовили транспоранты «Вечно мы лезем не в свое дело!» «Почему нам больше всех надо?» и «А потом мы же будем во всем виноваты!» 
[Mighty Ben-Yehuda roars and bellows

Today demonstrations in support of Ukraine will be held in the towns of Israel. The demonstrators have prepared banners "As ever we can't mind our own business!", "Why do we always need more than all the others?" and "Ultimately, we will be blamed for everything!"]

[http://beseder.ru/news/entryid/26, 15 June, 2015]

Conclusions

The material we have collected for this study clearly illustrates the folklorization of the conflict in the perception of the diaspora. While discussing events in Ukraine and expressing their attitudes and ideological positions, Russian-speaking Israelis appeal to Russian and Ukrainian literature and to traditional and contemporary folklore. A strong motif in discussions of events in Ukraine is the dehumanization of the other, be it Banderites, militants in Donbass or ideological opponents in Israel. This dehumanization follows traditional folkloric patterns, transforming the other into animals or insects and demonizing them.

The narratives about the conflict on both sides contain similar elements in terms of the topics discussed and arguments raised because they are rooted in the Soviet past, even among the members of the post-Soviet generation. The terms "fascists" and "Nazis" are used indiscriminately about opponents by both sides as the most damning accusation. Their meanings have considerably deviated from conventional definitions and they are part of hate language (and demonizing trends) permeating the narratives. They have become the basis for newly coined derivatives, such as naziki, zio-nazis, and nazio. The latter term is directly related to the Arab-Israeli conflict, which is represented by some discussants as having striking similarities with the Russian-Ukrainian crisis. Indeed, a distinctive feature of the Israeli diasporic discourse is that the crisis in Ukraine is often compared to the Arab-Israeli conflict and the problem of illegal immigrants. Finding similarities between militants in Ukraine and Hamas members, participants of the discussion demonstrate their involvement and anxiety about development of events both in the new and in the old country.

The jokelore that has emerged around the Ukrainian conflict brings together different time periods, historic figures, and distant places. The visuals also emphasize the merging of symbols -Russian, Ukrainian, Israeli- combined in such a way as to show the authors' affinities. The resulting world is absurd and macabre.

Facebook posts and the blogs that we monitored confirm that computermediated communication (CMC) is individualized and personalized, even if it is related to public matters and potentially can reach thousands of people worldwide. This mass self-communication [Castells 2007] gives users an opportunity not only to express themselves in groups that they choose but also to select content according to their needs [Valkenburg et al. 2015: 5]. Participation in online discussions shapes internet users' position on the conflict and appeals to "friends" 
to support, "like" and "share" are akin to social actions and may affect the users more strongly than mere facts would.

In the 1990s, the narratives of veteran Israelis about immigrants from the FSU were often hostile to the newcomers and they served to unify immigrants of the big wave; by contrast, the Ukrainian crisis is dividing the community. One has to admit that Ukrainian cultural life failed to develop at the level comparable with Russian cultural institutions in Israel. Clearly, immigrants from Ukraine were content to use Russian-Israeli media, educational institutions and community centers created by fellow-immigrants from the FSU. As a result, today their cultural consumption and informal communication are primarily in Russian or Hebrew, not in Ukrainian. While ideological division is sharp, these disagreements do not go beyond intra-community clashes, neither do they lead to the division of ex-Soviet diaspora into two-Russian and Ukrainian.

\section{NOTES}

1 The research reported here is a joint project. The authors alternate priority of authorship in their publications. We would like to express our gratitude to the anonymous reviewers for careful reading of the previous version of this essay and for helpful suggestions for revisions.

2 Dates after internet addresses indicate when the sites were accessed last.

3 Emigration from various regions of Ukraine, those controlled by the government and by the separatists continued in the second half of 2015. Some of the émigrés cannot manage relocation on their own and turn to help to NGOs. One of them, an American-based "Friendship Foundation" organized11 flights and in the period of nine months helped 1,400 families from Ukraine to immigrate to Israel [http://www.newsru.co.il/israel/21sep2015/ukr_0010.html, 22 September 2015].

4 Although Ukraine does not officially accept double citizenship, those who left the country after October 1991 can keep their passports and have the right to participate in the national elections. Russia, on the other hand, officially accepts double citizenship and pays old-age pensions to the émigrés, but on the 14th of August 2014 an amendment to the Federal law on the citizenship in the Russia was adopted requiring all carriers of double passports to declare it when visiting Russia [http://www.fmsmoscow.ru/docs/nationality/2nationality2014.html, 1 April 2015]. This controversial change caused by the aggravation in political and economic relations between Russia and the West sparked heated discussions in the Russian media and in the diaspora.

5 The Facebook groups that we monitored were all public and accessible to non-members: Izrail'tane za chestnuiu Rossiui $i$ svobodnuiu Ukrainu [Israelis for honest Russia and free Ukraine], Israeli Friends of Ukraine, Вести Израиль Vesty Israel, Ukraintsy V Izraile (Ukrainians in Israel). There are also closed groups which do not allow non-members to see discussion or post and comment, e.g., Israel help Maidan wounded. To remain impartial, we decided not to join 


\section{Russian-Speaking World}

any closed group. Personal Facebook pages are open only to "friends". As a rule, they do not concentrate on one topic and may contain personal information. We had access to them as "friends" and obtained permission from all those whose posts we wanted to quote.

6 We indicate a number of Facebook friends to show how many users the quoted posts reach. In those cases, when we are not "friends" with the author on Facebook we don't specify this number.

7 We translated excerpts from the posts without editing them in order to preserve the individual style of the Internet users. We also preserved such idiosyncrasies of online writing as a lack of capitalization. Instances of code switching and Hebrew and Ukrainian insertions in the Russian posts are italicized.

8 The term "political technologist" emerged in Russia in the 1990s during Yeltsin's rule. It is rarely used in the West and may be closest but not equivalent with more familiar "political consultant" and "political strategist." According to the historian and politologist Andrew Wilson, it involves a high degree of political manipulation [2011]. The term is used not only in the Russian language of the metropolis but also in the diaspora.

9 A. Dmytruk's song was translated into English by Andrey Knellera [https://www.facebook.com/knellera/posts/290782174430944, 18 September 2015] and these four lines quote from this translation. Trying to be loyal to the spirit of the original, Knellera's version changes some of the formulations thus allowing for shifts in the interpretation. For the sake of precision, we give our own translation of the contrasted pairs discussed above and in the criticism expressed by Aidelman further.

\section{BIBLIOGRAPHY}

“В ближайшую пятницу около посольства России в Тель-Авиве пройдет митинг в поддержку Украины" [On Friday near the Russian Embassy in Tel Aviv Will Host a Rally in Support of Ukraine]. Cited by http://newsru.co.il/israel/23apr2014/meeting_104.html. (consulted 24 September 2015).

“В Израиле прошла 'антибандеровская' акция памяти жертв Донбасса” [In Israel 'Anti-Banderite' Action Took Place in Memory of the Victims of Donbass]. Cited by http://nsn.fm/in-the-world/pamyat-zhertv-natsistov-ineofashistov-pochtili-v-izraile.php. (consulted 12 September 2015).

“В преддверии Йом Кипур фонд 'Керен едидут' доставил в Израиль 172 репатриантов из Украины” [On The Eve of Yom Kippur Fund 'Keren Edidut' Delivered 172 Immigrants from Ukraine]. Cited by http://www.newsru.co.il/israel/21sep2015/ukr_0010.html. (consulted 22 September 2015).

“О двойном гражданстве" [On Dual Citizenship]. Cited by http://www.fmsmoscow.ru/docs/nationality/2nationality2014.html. (consulted 1 April 2015). 
“Порошенко подписал указ о введении санкций против России” [Poroshenko Signs Decree Introducing Sanctions Against Russia]. Cited by http://urainform.com/ru/politics/2015/09/16/poroshenko-podpisal-ukaz-o-vvedeniisanktsij-protiv-rossii. (consulted 16 September 2015).

"Реве та стогне Бен-Йегуда" [Mighty Ben-Yehuda Roars and Bellows]. Cited by http://beseder.ru/news/entryid/26. (consulted 15 June, 2015).

Aidelman, David. Cited by https:/www.facebook.com/david.aidelman?fref $=$ ts. (consulted 20 September 2015).

"Aliyah Hits Ten-Year High: Approximately 26,500 New Immigrants Arrived in Israel in 2014." Cited by http://www.jewishagency.org/blog/1/article/31301. (consulted 15 June 2015)

Avakov, Arsen. 2014. 6 June, 2014. Cited by https://www.facebook.com/arsen.avakov.1/posts/648366948586748. (consulted 13 July 2014).

Belova, O.V. 2005. Белова, О. В. Этнокультурные стереотипь в славянской народной традиции. [Ethnocultural Stereotypes in the Slavic Folk Tradition, in Russian.] Moskva: Indrik.

Boym, Svetlana. 1994. Common places: Mythologies of everyday Life in Russia. Cambridge, Mass.: Harvard University Press.

Briman, Shimon. 2014. Бриман, Шимон. “Конфликт между Украиной и Россией расколол израильтян" [Ukrainian-Russian Conflict Has Split Israelis, in Russian]. Новое Время. Cited by http://nv.ua/opinion/briman/Bratya-poraznomu-konflikt-mezhduUkrainoy-i-Rossiey-raskolol-izrailtyan-579.html. (consulted 18 May, 2015).

Briman, Shimon. 2015. Бриман, Шимон. “Стреляющий нейтралитет: выборы в Израиле и конфликт России-Украины” [Neutrality Backfiring: Elections in Israel and the Russian-Ukrainian Conflict, in Russian]. Новое Время. Cited by http://nv.ua/opinion/briman/strelyayushchiy-neytralitetvybory-v-izraile-i-konflikt-rossii-ukrainy-39837.html, (consulted 18 May, 2015).

Castells, Manuel. 2007. "Communication, Power and Counter-Power in the Network Society." International Journal of Communication, 1: 238-266.

Dmitruk, Anastasia. Дмитрук, Анастасия. 10 March, 2014. Cited by https://www.facebook.com/siadmytruk/posts/605508626186444.

(consulted 15 September 2015).

Dmytro (@schnaps_ua). 2014. “RT@mudzhyri: Яценюк: «Мы ничего не должны РФ. Российский газ случайно попал на территорию Украины и заблудился»." [RT @mudzhyri: Yatsenyuk: 'We don't need the RF. Russian gas accidentally fell into Ukrainian territory and got lost']. Cited by https://twitter.com/schnaps_ua/status/505428270230540288. (consulted 29 August 2014). Tweet.

Ellen Rutten, Julie Fedor, and Vera Zvereva (eds.) 2013. Memory, Conflict and New Media: Web Wars in Post-Socialist States. London and New York: Routledge. 


\section{Russian-Speaking World}

Epstein, Alek. 2014. Эпштейн, Алек. “Оставаться людьми” [Remain Human]. Cited by http://www.svoboda.org/content/article/25373012.html. (consulted 13 July 2014).

Fialkova, Larisa, \& Yelenevskaya, Maria. 2005. "Incipient Soviet Diaspora: Encounters in Cyberspace" Narodna Umjetnost: Croatian Journal of Ethnology and Folklore Research, 42(1): 83-101.

Fialkova, Larisa, and Yelenevskaya, Maria. 2007. Ex-Soviets in Israel: From Personal Narrative to a Group Portrait. Detroit: Wayne State University Press.

Fialkova, Larisa, and Yelenevskaya, Maria. 2013. In Search of the Self: Reconciling the Past and the Present in Immigrants' Experience. Tartu: ELM Scholarly Press.

Fialkova, Larisa. 2007. Фиалкова, Лариса. Коли гори сходяться: нарис українсько- ізраӥлських фольклорних взаємин [When Mountains Meet: Essays in Ukrainian-Israeli Folklore Studies, in Ukrainian]. Kyiv: IMFE.

Gondolla, Gonny. Cited by https://www.facebook.com/gondolla.gonny?fref $=$ ts. (consulted 8 May 2014).

Hollingsworth, Ch. (2001) Poetics of the Hive: The Insect Metaphor in Literature. Iowa City: University of Iowa Press.

Ishchenko, Volodymyr. 2014. "Ukraine Has Ignored the Far Right for Too Long - It Must Wake Up to the Danger." The Guardian, 13 November, 2014. Cited

http://www.theguardian.com/commentisfree/2014/nov/13/ukraine-farright-fascism-mps, last accessed 18 May 2015.

Israel-For Ukraine without Bandera. 2015. Ізраїль - за Україну без бандерів. Facebook.com Cited by https://www.facebook.com/groups/ukr.bez.banderovcev/. (consulted 12 September 2015).

Khotinskii, Boris. 2015. Хотинский, Борис. “Запрос президенту Украины: за что израильтяне подверглись санкциям?” [Request for the President of Ukraine: Why Have the Israelis been sanctioned?] Cited by http://izrus.co.il/obshina/article/2015-09-18/28856.html. (consulted 19 September 2015).

Knellera, Andrey. “Анастасия Дмитрук” [Anastasia Dmitruk]. 19 May, 2014. Cited by https://www.facebook.com/knellera/posts/290782174430944. (consulted 18 September 2015).

Kulyk, Volodymyr. 2013. "War of Memories in the Ukrainian Media: Diversity of Memories, Political Confrontation and Production Technologies," in Memory, Conflict and New Media: Web Wars in Post-Socialist States. Ellen Rutten, Julie Fedor, and Vera Zvereva (eds). London and New York: Routledge, 63-81.

Luhn, Alec. 2015. "Ukraine bans journalists who 'threaten national interests' from country" Cited by http://www.theguardian.com/world/2015/sep/16/ukrainepresident-bans-journalists-from-country. (consulted 16 September, 2015).

Markowitz, Fran. 1995. "Emigration, Immigration and Cultural Change: Towards a Transnational Russian-Jewish Community? In Y Ro'i (ed.), Jews and 
Jewish Life in Russia and the Soviet Union. London: Frank Cass \& Co LTD, 403-414.

Marples, David. R. 2006. "Stepan Bandera: A Resurrection of a National Hero." Europe-Asia Studies, 58(4): 555-566.

Myronyvna, Mazur. Миронівна, Мазур. “Тарас Григорович Шевченко в англомовному світі” [Taras Shevchenko in the English-speaking World]. Cited by http://www.dnipro-ukr.com.ua/scenariy-5864.html. (consulted 10 September, 2015).

Narvselius, Eleonora. 2012. “The 'Bandera Debate': The Contentious Legacy of World War II and Liberalization of Collective Memory in Western Ukraine". Canadian Slavonic Papers, LIV (3-4): 469-490.

Nebol'sin, Genrik. 2015. Небольсин, Генрих. “Обзирая прессу” [Press Review] Cited by http://beseder.ru/right-news/entryid/219. (consulted 10 September, 2015).

Nossik, Anton. 2015. “Зачем Украине оружие” [Why Ukrainian Weapons]. Cited by http://dolboeb.livejournal.com/2771279.html. (consulted 12 February 2015).

Pesman, Dale. 2000. Russia and Soul: An Exploration. Ithaca, NY.: Cornell University Press.

Pozner, Vladimir. 2015. Познер, Владимир. “О «пятой колонне», выборах в Израиле и Франции, театре и Немцове" [About the 'Fifth Column', Elections in Israel and France, Theater and Nemtsov]. Познер Online. Cited by http://pozneronline.ru/2015/04/10968/. (consulted 22 September 2015).

Quinn, Allison and Alyona Zhuk. 2015. "Ukraine's Ban of Foreign Journalists Ignites International Ire." Cited by http://sofiaglobe.com/2015/09/17/ukraines-ban-of-foreign-journalistsignites-international-ire/. (consulted September 17, 2015).

Remennick, Larissa. 2002. Transnational Community in the Making: RussianJewish Immigrants of the 1990s in Israel. Journal of Ethnic and Migration Studies, 28(3): 515-530.

Rezunkov, Viktor and Sergei Dobrynin. 2014. Резунков, Виктор, Сергей Добрынин. “Научная диаспора: без политики?” [Research Diaspora: without Politics? In Russian]. Радио Свобода. 8 December, 2014. Cited by http://www.svoboda.org/content/article/26731993.html. (consulted 13 April 2015).

Shaus, Iakov. 2015. Яков Шаус. “Порошенко - главный враг свободы слова?” [Poroshenko is the Main Enemy of Freedom of Speech? Cited by http://mnenia.zahav.ru/Articles/6617/poroshenko. (consulted 24 September 2015).

“Статистика: темпы репатриации из Украины и России в 2015 году выше, чем из Франции" [Statistics: The Rate of Repatriation from Ukraine and Russia in 2015 is Higher Than From France]. Cited by http://www.newsru.co.il/israel/13jul2015/aliya_115.html. (consulted 12 September 2015). 


\section{Russian-Speaking World}

The Gist of Time, Israel. 2015. Суть времени, Израиль. Facebook.com Cited by https://www.facebook.com/groups/816878271675184/. (consulted 12 September 2015).

Tolts, Mark. 2001. “The Post-Soviet Jewish Emigration.” European Population Conference. Helsinki, 7-9 June, 2001. Cited by https://www.academia.edu/1565822/The_Post-Soviet_Jewish_Emigration. (consulted 31 March, 2015).

Torn, Boris. 2015. Торн, Борис. “Израильтяне - с Украиной” [Israelis and Ukraine]. Cited http://www.newswe.com/index.php?go=Pages\&in=view\&id=8001. (consulted 15 September 2015).

"Ukraine bans 41 international journalists and bloggers." Committee to Protect Journalists. Cited by https:/www.cpj.org/2015/09/ukraine-bans-41international-journalists-and-blog.php. (consulted 20 September 2015).

Valkenburg, Patti M., Peter, Jochen, \& Walther Joseph B. (2015) Media Effects: Theory and Research. Annual Review of Psychology, in press.

Voolaid, Piret. 2013. Click 'Like' and Post It on Your Wall! Chain Posts on Facebook - Identity Construction and Values. Folklore, 53: 73-98.

Vozniuka, Vasiliia. 2015. Вознюка, Василия. “Стой, кто идиот!” [Wait, who's the idiot!]. Беседер. Cited by http://beseder.ru/news/entryid/372. (consulted 10 September, 2015).

Wilson, Andrew. 2011. “'Political Technology': Why Is It Alive and Flourishing in the former USSR?" Cited by https:/www.opendemocracy.net/odrussia/andrew-wilson/political-technology-why-is-it-alive-and-flourishingin-former-ussr. (consulted 21 September 2015).

Yelenevskaya, Maria. 2009. "at Home with Violence: Israeli Russian-Language Media's Use of Cultural Codes in Interpreting Intifada. Hierarchy and Power in the History of Civilizations. Moscow: Uchitel', 122-137.

Yelenevskaya, Maria. 2009. Hierarchy and Power in the History of Civilizations. Moscow: Uchitel'.

Zudina, Alexandra. 2015. Зудина, Александра. "Петя и банк" [Petia and the Bank]. Беседер. Cited by http://beseder.ru/news/entryid/225. (consulted 10 September, 2015).

Zvezdochettt. 2015. "Как діды” [Like DiDy]. LiveJournal.com Cited by http://zvezdochettt.livejournal.com/298852.html. (consulted 8 May 2014) 